\title{
ICT adoption in affecting organizational performance among Indonesian SMEs
}

\author{
Lucy Chairoel \\ STIE Dharma Andalas, Indonesia \\ Email:lucy.chairoel69@gmail.com \\ Setyawan Widyarto \\ Selangor University, Malaysia \\ Email:swidyarto@unisel.edu.my \\ Vera Pujani \\ Andalas University, Indonesia \\ Email : vpujani@,fekon.unand.ac.id
}

\begin{abstract}
The objective of this research is to identify conceptually factors affecting ICT adoption and its impact among Indonesian SMEs. The prior studies involve conceptual model of the combination between Diffusion of Innovation (DOI) theory, The technology-organization-environment (TEO) theory, and Iocovou's framework. The prior studies believed the Internal and external factors influencing ICT adoption. This study found that the characteristic of technology, organization, and managerial are included as internal factors in adopting ICT. In the meantime, environment factors also are included as the external factor. Thus, the impact of ICT adoption would gave contributions on the efficiency and effectiveness of the organization as reflected in the organization performance. Hence, the organization performance could be measured based on the performance of business processes (operational performance) and financial performance (final performance). Reducing cost, increasing productivity related to operational performance, and profit margin, market share related to final performance. In brief, this study presents the conceptual framework of ICT adoption among Indonesian SMEs. Reviewing numerous prior studies to develop the research framework of this study is undertaken. However, the empirical study of current paper should be continued in the further research.
\end{abstract}

Key word: internal factor, external factor, ICT adoption, organizational performance, operational performance, final performance.

\section{Introduction}

Nowadays, the adoption of ICT by industries cannot be denied. Majority of ICT adoption is applied by large companies even SMEs. The ICT adoption development is not avoided by any business organizations. Such as the business activity tend to apply ICT that given the impact on SMEs business process. The large industries have concern with the use of new technologies in supporting the business. Over the past two decades, the using ICT by SMEs has generated a great deal of interest among researchers, governments, and international organizations. ${ }^{1}$ However, majority of SMEs is limited usage to adopt of ICT in business activities. $^{2}$

Several studies argue generally is still the slowness of SMEs to adopt ICT. ${ }^{3}$ This is supported by several research that exposes many factors affecting the adoption of ICT on SME in developing countries.

Despite the many obstacles of adoption of ICT SMEs in developing countries but slowly began to accept the use of ICT adoption. ${ }^{4,5,6,7}$. There is still lack of a model and framework used of SME in evaluating SMEs effectiveness and the impact ICT in developing countries. This is interesting to formulate the framework or model in the context of developing economic. ${ }^{4}$

We will start by presenting the literature review. Then we will suggest a conceptual modal regarding factor affecting ICT adoption and its impact among SMEs. Finally, we will suggest the limitation and the research perspective

\section{Literature Review}

The key question that we use to organize our perception is "How factors can affecting ICT adoption and its impact on an organization?". In order to answer that question, we think at least that the different concepts have to be clarified in order to present the theoretical background

\subsection{Factors affecting ICT Adoption}

An important and fast growing technological innovation during this century is computer-based information systems. Information system (IS) and Information technology (IT) an opportunity for business to improve their efficiency and 
effectiveness, and even to gain competitive advantage. ${ }^{8,9}$

The literature shows the diversity of different perspectives toward factors that affect IT adoption process. Most of these perspectives and studies have concentrated on influencing factors such as top management, organizational behavior and characteristics, firms' resources are internal factors, government, customers, supplier and external IT consultant, vendors are external factors. ${ }^{10}$

The previous study e-commerce recommend the technology-organization-environment (TOE) framework can absolutely provide an appropriate starting point for studying e-commerce adoption. ${ }^{11}$ The TOE framework was developed by Tornatzky and Fleischer. ${ }^{12}$ Three aspect from TEO framework that affect the process adopts and implements a technological innovation. This framework is consistent with the diffusion of innovation (DOI) theory by Rogers ${ }^{13}$ emphasized individual characteristic and both internal and external characteristics of the organization in study of drivers for new technology. ${ }^{10,14}$ Technology, organizasation, and managerial characteristic are internal factors, environment is external factor.

In this research, the influencing of adoption of information system and e -commerce have been adjusted for ICT adoption. In the following section ICT adoption is discussed as the dimensions of technology, organization, managerial characteristic, environment, and organization performance.

\section{Internal Factors \\ Technology/Innovation of ICT}

Technology/Innovation is seen as a necessary measure for adoption, when adopt and use ICT. The other study describe that technological factors will be a technology viable whether it is perceived usefulness and easy of use are considered reasons for adoption. ${ }^{15}$ Dimension of technology factors based on DOI (Diffusion of Innovation) model. Rogers (1995) ${ }^{13}$ introduced the DOI model, namely a popular model in investigation of the behavior of users in adopting new technological innovation. This model proposed five perceived characteristics of innovation which consists of relative advantage, compatibility, complexity, trialability and observability.

Golding et al (2008) ${ }^{18}$ argued that relative advantage was expressed by perceived benefit. Perceived benefits include reduce transaction cost, improved cash flow, increase productivity, and better customer service. ${ }^{16,17,18,19 .}$ Compatibility included dynamic content, experience and needs of potential adopters, resistance to change, support from the top management, suitability of business processes with suppliers and customers. ${ }^{18,19,20,21}$. Complexity measured based on difficult to use, problems with locating desired information, rapid changes and technological advances, technical constraints, the skills and training required, complex to skill for employee. ${ }^{19,20,21,22}$

Trialability is defined he degree to which an innovation can be used on a trial basis before confirmation of the adoption must occur. ${ }^{18}$ Furthermore, It can be measured in the presence of advice from consultants, opportunity to test the technology, experiment with ICT tools, ability employee, much effort in testing technology, the new technology complicated to use. ${ }^{18,}$ ${ }^{21}$ Observability refer to the degree of visibility of the new technology results. ${ }^{23}$ These as a measure of observability of technology which included positive results of using ICT, benefit of ICT usage, customer satisfaction, profit, productivity, product quality, and abreast with competition. ${ }^{18,21,24}$

The DOI model is a popular model to investigate DOI in different sectors of the economy including SMEs. This model is inclined toward investigating new technology and diffusion. ${ }^{13}$ Hence, The main focus this study that it attempt to identify innovative characteristic rather than the whole innovation process. ${ }^{23,25}$

Beside the five characteristic in DOI, many previous study have recognize ICT security (confidentially) and cost as significant factors affecting ICT adoption. This is supported by Ghobakhloo et al ${ }^{26}$ and Irefan et al ${ }^{27}$, cost of IT adoption is influencing IT adoption in SMEs. Contrast by $\mathrm{Al}$ Qirim $^{28}$, the financial cost of operating and implementing the e-commerce application was not influence adoption. This is supported by Tan \& $\mathrm{Eze}^{29}$, ICT cost is not a significant contributor to ICT adoption. According to Ghobakhloo ${ }^{11}$, IS adoption is also influenced by indirect cost ( such as the costs of human factors or training) and direct cost ( such as cost of IS adoption and maintenance for IS adoption). In this study using direct cost and indirect cost, so that factors affected cost in ICT adoption are the cost of ICT adoption, the amount money and time of training, maintenance and support fees.

Security, the literature reveal that one of the main reasons that determine innovation adoption was ICT security and confidentiality. ${ }^{20,28}$ The many organizations are reluctant to embrace e-commerce mainly as security issues. SMEs may face security problems in many forms, including payment security, privacy and confidentiality of the information or viruses. The major barrier to wider adoption of e-commerce is security and the ability of organization in the forms of confidentiality, integrity and availability of information assets. ${ }^{30}$ Based on the above description, measurement of the security in this study was related with business transaction, confidential data, risk of business, and privacy. The table 1 list the factor of technology in previous 
Table 1. Factor of technology variable in previous studies

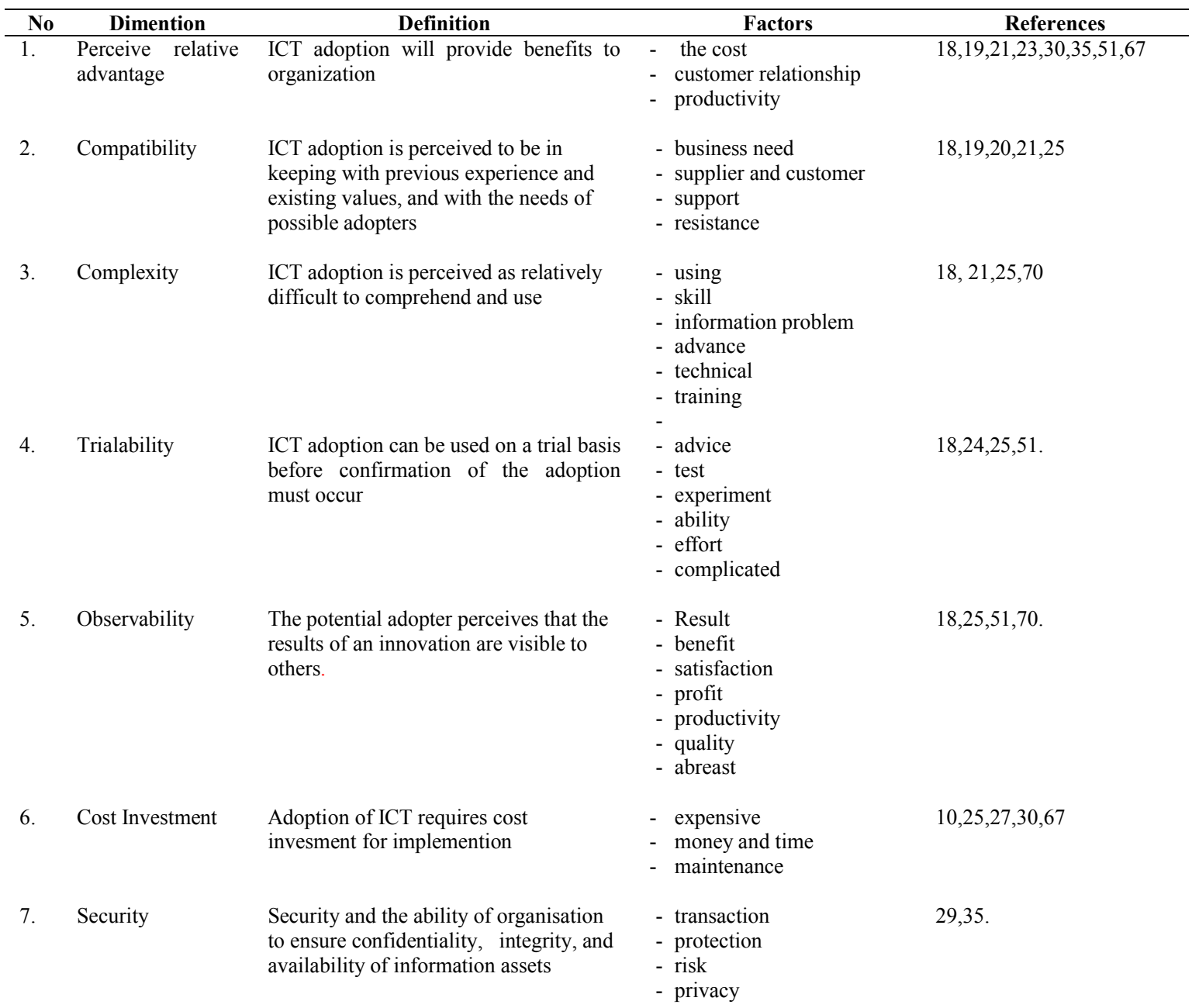

In this study, these seven characteristic would be dimention of technology variable developed from prior study concerning influence technology adoption.

\section{Organization}

Organization tends to adopt the technology if the consistency with their culture, values, preferred work practices and the availability of the infrastructure. Geographically, organization that has international or global orientation ${ }^{31,8}$ will accelerate the adoption process of ICT. ${ }^{19}$ The global scope enables the cost efficiency to get the new market, new customer and the distribution of goods and services and also to improve the coordination between suppliers and business collegague.

In using ICT adoption globally, it needs resources. In a company, the most important resources to adopt the new technology consist of finance, human and technology resources (computers, telephone lines, cables, etc). ${ }^{32,9,19}$ Especially in SMEs, if themanager views and think about the important of ICT adoption without followed with the resources that thecompany had.This part becomes the challenge for the SMEs in Indonesia to adopt ICT caused by the lack of finance, education, and innovation. ${ }^{33}$

As the explanation above, human resouce is important. Human resouce in a company is the employees. the emlpoyee's knowledge is really important to the company's ability in adopting ICT and using it. In adaptating with the new technology, it needs the changing in work behavior, qualification and knowledge about the technology itself. One of the reason to not to adopt IC is the lack of the internal skill ${ }^{34}$, it cause a company postpone the adoption of ICT. ${ }^{9}$ As long as the employee has the knowledge about ICT, so the organization tends to adopt it. ${ }^{19,35,36}$

Companies or organizations that adopt ICT must be supported by the strategy of the company. This is supported by the statements of ${ }^{19}$, that the orientation of the strategy on corporate organization becomes a factor to influence the adoption of technology. The orientation of the strategy used to see company involvement in the analysis and planning of strategy, so it can be examined from risk strategy and help speed up the adoption process technology. ${ }^{31}$ 
From the explanation above it can be concluded that there are four dimentions of organizational variable that is knowledge, resources, strategic orientation, globalization. All dimentions is explained by the below of the Table 2 :

Table 2. Factors of organizational in previous studies

\begin{tabular}{|c|c|c|c|c|}
\hline No & Dimention & Definition & Factors & References \\
\hline 1 & Knowledge & Knowledge and proficiency in using of ICT. & $\begin{array}{l}\text { - Knowledgeable } \\
\text { - competent } \\
\text { - proficience }\end{array}$ & $9,19,35,71$ \\
\hline 2 & Resources & $\begin{array}{l}\text { ICT adoption needs the financial resources, } \\
\text { human and information technology }\end{array}$ & $\begin{array}{l}\text { - financial } \\
\text { - technology } \\
\text { - human }\end{array}$ & $9,10,19,32$ \\
\hline 3. & $\begin{array}{l}\text { Strategic } \\
\text { Orientatiom }\end{array}$ & $\begin{array}{l}\text { The use of ICT adoption has the orientation } \\
\text { to strategy, coordination and the suitability. }\end{array}$ & $\begin{array}{l}\text { - Sstrategic } \\
\text { - coordination } \\
\text { - alignment }\end{array}$ & $19,31,72$ \\
\hline 4. & Globalization & $\begin{array}{l}\text { Oriented globalization will help the } \\
\text { accelerate of ICT adoption. }\end{array}$ & $\begin{array}{l}\text { - competitiveness } \\
\text { - participation } \\
\text { - relatedness }\end{array}$ & $19,31,71$ \\
\hline
\end{tabular}

The dimensions of the organization's research focuses on corporate strategy and the resources that exist in the company.

\section{Managerial Characteristic}

Managerial characteristic in this research explain about people to make decision in SMEs just like owner's, chief executive officer (CEO) or top manager. A number of research stated that the individual characteristics play a crucial role in the implementation of new technology. ${ }^{37,38,39}$

The characteristics of the individuals represented by the CEO or owner's on SMEs is an important part in adopting ICT. Some research found that the positive impact of knowledge CEO ICT adoption ${ }^{40}$ and experience of the CEO is another trait that influence of ICT in SMEs. ${ }^{41,42,10,43,44}$

According to Jeon in Korea ${ }^{71}$ CEO's knowledge largely determine the adoption of e-business. While the research results Huy in Viet Nam ${ }^{19}$ knowledge is insignificant against the use of ICT adoption.

Addition the influence of the use of ICT indicated by the attitude of top managers (CEO) or owners. ${ }^{18,45}$ Some of the literature supports the statement above who said that the existence of a strong link between CEOs attitude towards its implementation and success does ICT. ${ }^{46,47,19}$

Some researchers have also suggested that a positive attitude toward ICT does correlate with the spread of the use of, and development. ${ }^{48,49,9,8,19}$ The table 3 below describes the dimention and factors of the managerial characteristic :

Table 3. Factors of managerial characteristic in previous studies

\begin{tabular}{|c|c|c|c|c|}
\hline No & Dimention & Definition & Factors & References \\
\hline 1 & $\begin{array}{ll}\text { Attitude } & \text { toward } \\
\text { innovation } & \end{array}$ & $\begin{array}{l}\text { The manager's positive } \\
\text { behavior to the use of } \\
\text { technology. }\end{array}$ & $\begin{array}{ll}\text { - } & \text { attitude } \\
\text { - } & \text { receptive } \\
\text { - } & \text { capability } \\
\text { - } & \text { realize }\end{array}$ & $8,9,19,28,71$ \\
\hline 2 & $\begin{array}{l}\text { Knowledge of the } \\
\text { new IT }\end{array}$ & $\begin{array}{l}\text { The knowledge of the managers } \\
\text { about technology. }\end{array}$ & $\begin{array}{l}\text { - Use } \\
\text { - awareness } \\
\text { - rapid }\end{array}$ & $8,9,10,19$ \\
\hline
\end{tabular}

Besides organizational characteristic, the individual characteristics are also importance has been investigated. So that this study have focused on characteristics of the managerial or CEO (owner). ${ }^{8}$ In this study, three factors consisting of technological, organizational, and managerial inserted into the internal factors that influence ICT adoption.

\section{External factor; Environment}

Environment in research is something that outside their organization and cannot be controlled that is goverment, customer and suppliers pressure.
The environment have a strong impact of the decision to adopt ICT. ${ }^{39}$

Government play an important role in the development of the use of ICT in the SMEs. Literature also said there is a significant positive relationship between ICT and government support. ${ }^{23,26}$ Due to its size and lack of resources of SMEs so that the need for support and external resources. ${ }^{47}$ Fink ${ }^{41}$ argues the government support facilitates the transfer of information for SMES is increasing gradually. Government support to the adoption of e-commerce in Brunei is still low research based Looi ${ }^{35}$ This statement is supported by $\mathrm{Teo}$ et al ${ }^{34}$ that his Government's role in the 
Smash in Singapore in adopting on the Internet. In contrast with research ${ }^{23,10}$, the Government's role is very significant to help and encourage the adoption of ICTs on SMEs.
Beside the government, customers and suppliers also included the factor of environment. Because of the pressure from buyers and suppliers also affect the adoption of ICT in SMEs. $48,39,49,14,11,22,50$

Table 4. Factors of environment variable in previous studies

\begin{tabular}{lllll}
\hline No & Dimention & \multicolumn{1}{c}{ Definition } & \multicolumn{1}{c}{ Factors } & \multicolumn{1}{c}{ References } \\
\hline 1 & Government & $\begin{array}{l}\text { The support from the } \\
\text { government to the use of ICT } \\
\text { adoption. }\end{array}$ & $\begin{array}{l}\text { - fund } \\
\text { - assistance } \\
\text { - information } \\
\text { 2. encouragement }\end{array}$ & $10,19,31,35,67,71,77$ \\
2. & $\begin{array}{l}\text { Customer } \\
\text { supplier }\end{array}$ & $\begin{array}{l}\text { The influence of customers } \\
\text { and suppliers to the use of ICT } \\
\text { adoption. }\end{array}$ & $\begin{array}{l}\text { - pressure } \\
\text { - demand }\end{array}$ & $10,19,22,35$ \\
& & - counterpart
\end{tabular}

This study concentrates on two such factors: goverment and customer and supplier pressure. Goverment is critical in supporting the ICT adoption on SMEs in developing countries. The many obstacles on SMEs to undertake the adoption technology. ${ }^{51,27}$ Customer and supplier of pressure will force SMEs to use ICT adoption in order to improve the marketing of its product. External factor in this study is environment due to this factor is outside the organization and difficult to control

\subsection{Impact ICT Adoption}

A number of studies show the effects of various technologies, that is used and the level of the adoption on the performance of companies with demonstrated complementary between technological and organization change. ${ }^{52}$ Several type of performance measured based on the literature of ICT such as financial performance, and operational performance ${ }^{53}$, and other impacts. ${ }^{54}$

The efficient use of ICT in SMEs lead to increased organizational performance, productivity, and access to market. ${ }^{55}$ Organizational performance includes the increase in sales, market share and profitability compared to competitors. ${ }^{56}$ Consequently, a significant positive in organizational performance toward $\mathrm{ICT}^{57}$ is vital to SMEs. ${ }^{58}$

\section{Operational Performance}

Operational performance is one of the organization performance in the short time in using of ICT adoption. The impact of operational performance in using measures productivity, cost reduction $^{59,60,61}$, new products development, services and processes, quality improvement in products and services, and increased speed in product delivery. ${ }^{56}$

Additional operational performance can be measured by unit cost of production, product specifications, delivery performance, product development, product innovation, and customer support and services. According to the Lii et all ${ }^{62}$ performance of online marketing which is part of ICT can increase the productivity, efficiency, percentage of new customer, percentage online sales.

So the operational performance in a short-term impact from the use of ICT can enhance the business development does, efficiency and customer satisfaction. The operational performance in this research prioritized on the product and service on SMEs that have used ICT adoption since it is directly related to the consumer

Table 5. Factors of Operational Performance in previous studies

\begin{tabular}{lll}
\hline No & \multicolumn{1}{c}{ Factors } & \multicolumn{1}{c}{ Reference } \\
\hline 1. & productivity & 52,83 \\
2. & cost & $52,60,83$ \\
3 & new products development & 52,85 \\
4 & services and processes & $82,83,85$ \\
6 & quality improvement in products and services & $52,84$. \\
7 & speed in product delivery & $52,85$.
\end{tabular}

\section{Final Performace}

The company implemented the use of ICT adoption in order to generate positive performance of organizations like the margin of profit and the profit resulting from the growth of e-commerce that is part of ICT does. The overall impact of the organization measured using margin and profit ${ }^{60}$ and increased market share. ${ }^{52}$ Generall, it shows the final performance is the impact of ICT 
does in the long run that will affect the company as a whole.

Table 6. Factors of Final Performance in previous studies

\begin{tabular}{lll}
\hline No & \multicolumn{1}{c}{ Factors } & \multicolumn{1}{c}{ Reference } \\
\hline 1 & profit & $52,60,67,83,84$ \\
2 & Market share & $52,67,84$
\end{tabular}

In this study, the final performance is addressed to the organization's performance related to finance and the ability to dominate the overall market.

\section{Conceptual model of research}

In the conceptual model we tried to show the factors affecting ICT adoption and its impact to organization performance. The H1a, H1b, H1c concern to internal factors as affecting ICT adoption. $\mathrm{H} 2$ is external factor to influence ICT adoption. H3, H4, H5 analyze impact of ICT adoption on organization.

\subsection{ICT Adoption}

ICT adoption construct in this study focuses on the actual uses of ICT as the use of computers, internet access, use for communication, as well as for marketing. The use of ICT is focused on the use of the organization. Actual of use are shown in search of information, receipt of orders from customers, receiving payments from consumers, consumer service receipts, purchase orders, payments to vendors. ${ }^{52,63,64,65,66}$ Also, the use of ICT by SMEs is indicated by marketing and the communication tools used between company and users, and between customers and business partners.

Some literature shows the use of ICT adoption is influenced by internal and external factors of organizational. ${ }^{51,5,10}$ Internal factors affecting the use of ICT is technology, organization, managerial characteristic whereas ekternalnya factor is environment

Technologies are defined and presented in a variety of dimensions consisting of perceived relative advantage, compatibility, complexity, trialability, observability, cost investment and security. Regarding the perceive relative advantage, past study ${ }^{28,67,68,10,69,70,35,25}$ have shown statistically for significant to use of ICT. Meanwhile, compatability is also reported to have significance with ICT adoption such as business need, supplier andcustomer, and top management support. ${ }^{70,15,10 \text {, }}$ 18,25

At same time, complexity andtrialability have significant to using ICT adoption such as use, skill, technological advance..$^{70,22,21,23}$ In additional, observalidity has also significant to use ICT such as satisfaction, profit, productivity. ${ }^{51,18,70,21,25}$ Besides that cost invesment and security will effect the degree of ICT adoption. ${ }^{28,10,27,35,25}$ These constructs arenecessary in encouraging users to use ICT. The relationship between technology and ICT adoption is presented in the first a hypothesis of this research

Hla : There is the significant relationship between technology factors and ICT adoption among Indonesian SMEs

Organization is also associated with ICT. The literature reported that ICT adoption which may include employee, resources, strategic, and globalization $^{71,19,10,31}$ play a important role in the adoption of new technology ${ }^{72,9,73}$ The study in SME's Vietnam, the determinant of e-commerce adoption is the employees' knowledge and the resources of enterprise. ${ }^{19}$ Thefirm's strategy orientation can play an important role in the adoption of information technology. ${ }^{74,73}$ The global reach of the internet makes morebeneficial, as a consequence firms with greaterglobalization are likely to use e-business. ${ }^{31}$ The above discussion lead to the follwing hypothesis.

$H 1 b$ : There is the significant relationship between organization factors and ICT adoption among Indonesian SMEs

We investigate specifically two factors from managerial characteristic i.e attitude toward innovation and knowledge of managers. The literature suggests a clear link between the attitude of the CEO towards IT and successful application of IT. ${ }^{19}$ A number of authors have posited that positive attitude toward general IT adoption and e-commerce. ${ }^{10,19,8}$ Manager who has knowledge of information technology has an effect on the adoption of e-commerce ${ }^{8}$, and their knowledge of new technologies and e-commerce has a positive effect on the level of use of ecommerce $^{71,32}$ As a result, we proposed the following hypotheses for the context of ICT adoption :

\section{H1c: There is the significant relationship between managerial characteristic factors and ICT adoption among Indonesia SMEs}

The environment (extrenal industry) plays a significant role in the adoption of new technologies and considered in IT innovation adoption in organization. ${ }^{75}$ External industry refer to trading partner (buyer and supplier) and goverment policies. $^{76}$ According to previous study pressure from buyer and supplier seemed to be logical reason for adopting $\mathrm{EDI}^{28}$, e-commerce ${ }^{51,10,19}$, and 
ICT adoption. ${ }^{67}$ This is supported by ${ }^{69}$ states that supplier and customer had strong influence on IT adoption. Another reason for small businesses to adopt IT comes from government policy. The number of study showing goverment support for ecommerce $^{51,15,71,35,77}$ and ICT adoption ${ }^{67,27}$ in various develop and developing countries. The second hypothesis presents the relationship between environment and ICT adoption as below :

H2 : There is the significant relationship between environment factors and ICT adoption among Indonesian SMEs.

\subsection{Operational Performance}

The study of Anh \& Matsui, 2011 result that quality management information (QMI) significantly affect the different dimensions of the operational performance of the various countries. According to Bayo et al ${ }^{52}$ reveal ICT resources are positively associated with operational performance. This is supported by Gibbs et al, ${ }^{78}$ E-commerce is an additional channel on the firms for doing business as a means to reduce costs as a means to improve operational performance. Many SMEs have not yet reached a level of maturity that most SMEs expect a short term increase of operating performance. $^{79}$ The relationship between ICT adoption and operational performance are presented in the third hypothesis :

H3 : There is the significant relationship between ICT adoption in Indonesian SMEs and operational performance

\subsection{Final Performance}

Based on some types of ICT are investigated by Bayo et al ${ }^{52}$ showed a significant relationship between operational performance with the final performance. Type of ICT distinguished on the term of general use, communication and market oriented. This is supported by Paul \& Anantharaman $^{80}$ reveal the effective operational performance will affect financial performance of an organization. The relationship between operational performance and final performance are presented in the four hypothesis :

H4 : There is the significant relationship between operational performance and final performance in Indonesia SMEs.

According to Apulu ${ }^{58}$, ICT adoption on SME's Nigeria has been identified may increase profit caused ICT utilization in marketing can increase profit (final performance) in many organization. The various evidence at the firm level as to impact of IT capital on financial performance measures such as profit and market value (final performance). ${ }^{81}$ ICT impact on final performance (market share and profit) occur mainly indirectly by means of the improvement of internal and external communication as through operational performance. $^{52}$ It shows the influence of ICT adoption on the finalperformance of the company. The fifth hypothesis looks at the relationship between ICT adoption and final performanc

H5 : There is the significant relationship between ICT adoption and final performance in Indonesia SMEs

Figure 1 shows proposed conceptual framework that integrates the influences and impacts of ICT adoption. The results of a literature review suggest 7 hypoteses. There are 7 determining factors of ICT adoption consisting of technology, organizational, managerial characteristic, environment, ICT adoption, operational performance and final performance.

\section{Implication and research limitation}

The finding carry theoritical implications for the ICT adoption literature as they extend the scope of the research on organizational performance. More over, this research allows managers to recognize better how to manage organization the effeciency and effectively and to expand uses ICT adoption ion company with the aim of identifying organization performance.

This research has limited consist of the model is derived from related the literature, combine Tornatzky and Fleischer's model ${ }^{12}$, Roger' model ${ }^{13}$, Iocovou model ${ }^{82}$ and is then adjusted to organizational perspective and Indonesia context. ICT adoption in research focus in basic and intermediate uses ICT in SMEs.

\section{Conclusion}

Nowdays, the adoption of ICT by industries cannot be denied. Majority of ICT adoption is applied by large companies even SMEs. The ICT adoption development is not avoided by any business organization, such as the business activity tend to apply ICT that given the impact on SMEs business process. However majority of SMEs is limited usage to adopt of ICT in business activities. This is caused internal and external factors. This research will look at the factor that influence the use of ICT adoption among SMEs.

Furthermore, In general the use of ICT is also the impacted on organization performance. Organization performance refer to ICT contributions to organization, including cost saving, expanded markets, additional sales, reduced costs, time saving, productivity, profitability, and market 
value. In this research, organization performance devided into 2 (two) ; (1) operationl performance ( the performance of business process). (2) final performance (the performance of financial)

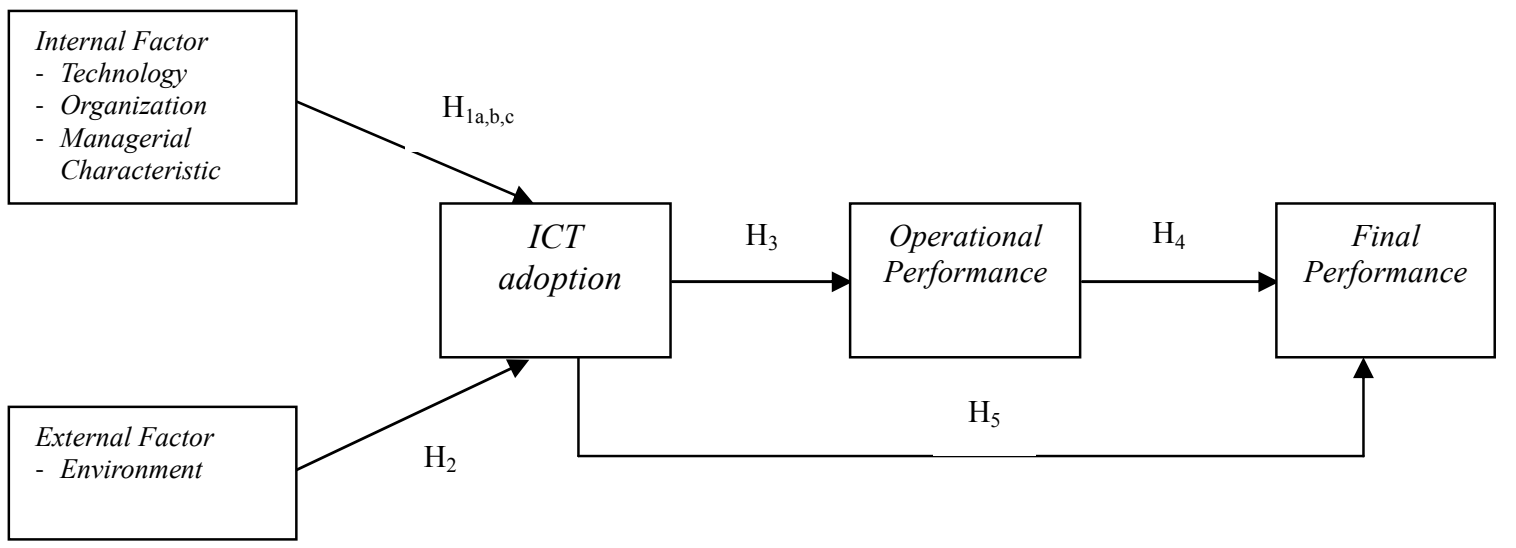

Figure1 : The Proposed Framework of The Research

Source : Iocovou (1995), Roger's (1995), Tornatzky \& Fleischer (1990)

\section{References}

1. D. Kabongo, J., \& O. Okpara, J, ICT possession among Congolese SMEs: an exploratory study. Journal of Small Business and Enterprise Development, 21(2), 2014, 313-326. doi:10.1108/JSBED-10-2013-0143

2. OECD, ICT, E-Business and SMEs, 20040.

3. Alzougool, B., \& Kurnia, S, Electronic Commerce Technologies Adoption by SMEs: A Conceptual Study. Australasian Conference on Information Systems, 2008, (pp. 1-10).

4. Ndiege, J. R. A., Herselman, M. E., \& Flowerday, S. V, Information and Communication Technologies within Small and Medium Enterprises in Developing Economies. African Journal of Business Management, 6(10), 2012, 3576-3582. doi:10.5897/AJBM11.2866

5. Kapurubandara, M, A Framework to ETransform SMEs in Developing Countries. EJISDC, 39(3), 2009, 1-24.

6. Duncombe R, The growth and formalisation of information systems in developing country SMEs. IDPM Dev. Informatics Working, 2005, p. 24.

7. Kyobe, M, Investigating the key factors influencing ICT adoption in South Africa. Journal of Systems and Information Technology, 13(3), 2011, 255-267. doi:10.1108/13287261111164844

8. Thong, J.Y.L., \& Yap, C. S, CEO characteristics, organizational characteristics and information technology adoption in small businesses. Omega, 23(4), 1995, 429-442. doi:10.1016/0305-0483(95)00017-I

9. Thong, James Y.L, An Integrated Model of Information System Adoption in Small Businesses. Journal of Management Information Systems, 15(4), 1999, 187 - 214.

10. Ghobakhloo, M., Sabouri, M. S., Hong, T. S., \& Zulkifli, N, Information Technology Adoption in Small and Medium-sized Enterprises; An Appraisal of Two Decades Literature. Interdisciplinary, Journal of Research in Business, 1(July), 2011, 53-80.

11. Ghobakhloo, M., Arias-Aranda, D., \& BenitezAmado, J, Adoption of E-Commerce Applications in SMEs. Industrial Management \& Data Systems, 111(8), 2011, 1238-1269. doi:10.1108/02635571111170785

12. Tornatzky, L. and Fleischer, M. The process of technology innovation, Lexington, $M A$, Lexington Books, 1990)

13. Rogers, E.M, Diffusion of innovations, Fourth Edition ed., New York, Free Press, 1995)

14. Oliveira, T., \& Martins, M. F, Literature Review of Information Technology Adoption Models at Firm Level. EJISE, 14(1), . 2011, 110-121.

15. Azadegan, A., \& Teich, J, Effective benchmarking of innovation adoptions: A theoretical framework for e-procurement technologies. Benchmarking: An International Journal, 17(4), 2010, 472-490. doi:10.1108/14635771011060558

16. Aghaunor, L., \& Fotoh, X, Factors Affecting Ecommerce Adoption Nigerian Banks, Report., 2006). 
17. Beatty, R. C., Shim, J. P., \& Jones, M. C, Factors infulencing corporate web site adoption : a time-based assessment. Information \& Management, 38(6), 2001, $337-354$

18. Golding, P., Donaldson, O., Tennant, V., \& Black, K, An Analysis of Factors Affecting The Adoption of ICT by MSMEs in Rural and Urban Jamaica. ECIS 2008 Proceedings Website (p. 237). Jonkoping International Business School Jonkoping University, 2008).

19. Huy, L. E. Van, Rowe, F., \& Truex, D, An empirical Study of Determinants of Ecommerce Adoption in SMEs in Vietnam an economy in transition. Journal of Global Information Management (JGIM), 20(3,. 2012).

20. Hussin, H., Nor, R. M., \& Suhaimi, M. A, Perceived Attributes of E-Commerce and the Adoption Decision: The Case of Malaysian SMEs. Jurnal Teknologi Maklumat \& Multimedia, 5, 2008,. 107-125

21. Soh, C., \& Chew, D., The Use of the Internet for business : the Experience of Early Adopters in Singapore. Internet Research: Electronic Networking Applications and Policy, 7(3), 1997, 217-228

22. Premkumar, G., \& Roberts, M., Adoption of New Information Technologies in Rural Small Businesses. Omega, 27(4), 1999, 467-484. doi:10.1016/S0305-0483(98)00071-1

23. Tan, K. S., Chong, S. C., Lin, B., \& Eze, U. C., Internet-based ICT Adoption: Evidence from Malaysian SMEs. Industrial Management \& Data Systems, 109(2), 2009, 224-244. doi:10.1108/02635570910930118

24. Moghavvemi, S., Hakimian, F., \& Feissal, T. M. F., Competitive Advantages Through IT Innovation Adoption by SMEs. Social Technologies, 7564(1), 2012, 24-39.

25. Tan, K., Eze, U., \& Chong, S., Effects of Industry Type on ICT Adoption Among Malaysian SMEs. Journal of Supply Chain and Customer Relationship Management, 2012, 112. doi:10.5171/2012.113797

26. Ghobakhloo, M., Hong, T. S., Sabouri, M. S., \& Zulkifli, N., Strategies for Successful Information Technology Adoption in Small and Medium-sized Enterprises. Information, 3(4), 2012, 36-67. doi:10.3390/info3010036

27. Irefin, I. ., Abdul-Azeez, I. A., \& Tijani, A., A. An Investigative Study of The Factors Affecting The Adoption of Informatin and Communication Technology in Small Medium
Scale Enterprise in Nigeria. Australian Journal of Business and Management Research Vol.2, 2(02), 2012, 1-9

28. Al-qirim, N., The adoption of eCommerce communications and applications technologies in small businesses in New Zealand. Electronic Commerce Research and Applications, 6, 2007, 462-473. doi:10.1016/j.elerap.2007.02.012

29. Tan, K. S., \& Eze, U. C., An Empirical Study of Internet-Based ICT Adoption Among Malaysian SMEs. Communications of the IBIMA , 1, 2008, 1-12

30. Kannabiran, G., Enablers and inhibitors of advanced information technologies adoption by SMEs An empirical study of auto ancillaries in India. Emerald, 25(2), 2012, 186 - 209. doi:10.1108/17410391211204419

31. Zhu, K., \& Kraemer, K. L., Post-Adoption Variations in Usage and Value of E-Business by Organizations: Cross-Country Evidence from the Retail Industry. Information Systems Research, 16(1), 2005, 61-84. doi:10.1287/isre.1050.0045

32. Rashid, M. A., \& Al-Qirim, N., E-Commerce Technology Adoption Framework by New Zealand Small to Medium Size Enterprises 2 Ecommerce in New Zealand. Research Lettersin the Information. Mathematical Sciences, 2, 2001, 63-70

33. Tambunan, T. T. H., Development of Small and Medium Enterprises in A Developing Country: The Indonesian Case. Journal of Enterprising Communities: People and Places in the Global Economy, 5(1), 2011, 68-82. doi:10.1108/17506201111119626

34. Teo, T. S. ., \& Tan, M., An Empirical Study of Adoptors and Non-Adopters of The Internet in Singapore. Information \& Management, 34(6), 1998, 339-345. doi:10.1016/S03787206(98)00068-8

35. Looi, H. C., E-Commerce Adoption in Brunei Darussalam: A Quantitative Analysis of Factors Influencing Its Adoption. Communications of the Association for Information Systems, 15(3), . 2005, $61-81$

36. Molla, A., \& Licker, P. S., Perceived EReadiness Factors in E-Commerce Adoption: An Empirical Investigation in a Developing Country. International Journal of Electronic Commerce, 10(1), 2005 83-110. Retrieved from http://ictlogy.net/bibliography/reports/projects.p $\underline{\mathrm{hp} \text { ? idp }=1029}$ 
37. Mahmood, M.A., Hall, L., Swanberg, D.L., Factors affecting information technology usage: a meta-analysis of the empirical literature. Journal of Organizational Computing and Electronic Commerce 11 (2), (2001,107-130.

38. Venkatesh, V. and Morris, M. G., Why Don't Men Ever Stop to Ask For Directions? Gender, SocialInfluence, and Their Role in Technology Acceptance and Usage Behavior, MIS Quarterly (24:1), . 2000,. pp. 115-139

39. Bayo-Moriones, A., \& Lera-López, F., A firmlevel analysis of determinants of ICT adoption in Spain. Technovation, 27(6-7), 2007, 352366. doi:10.1016/j.technovation.2007.01.003

40. Drew, S., Strategic Uses of E-Commerce by SMEs in the East of England. European Management Journal, 21(1), 2003, 79-88. doi:10.1016/S0263-2373(02)00148-2

41. Fink, D., Guidelines for the Successful Adoption of Information Technology in Small and Medium Enterprises. International Journal of Information Management, 18(4), 1998, 243253. doi:10.1016/S0268-4012(98)00013-9

42. Lybaert, N., The Information Use in a SME: Its Importance and Some Elements of Influence. Small Business Economics, 10(2), 1998, 171191.

43. Mehrtens, J., Cragg, P. B., \& Mills, A. M., A model of Internet adoption by SMEs. Information \& Management, 39(3), 2001, 165176. doi:10.1016/S0378-7206(01)00086-6

44. Seyal, A. H., \& Rahman, M. N. A., An Extension of the Technology Acceptance Model : The Case of Bruneian Managers. Asian Journal of Business and Accounting, 2(1 \& 2), 2009, 25-45

45. Poon, S., \& Swatman, P. M., An Exploratory Study of Small Business Internet Commerce Issues. Information \& Management, 35(1), 1999, 9-18. doi:10.1016/S03787206(98)00079-2

46. Seyal, A. H., \& Rahim, M. M., A Preliminary Investigation of Electronic Data Interchange Adoption Bruneian Small Business Organization. EJISDC, 24(4), 2006, 1-21

47. Sarosa, S., \& Zowghi, D., Strategy for Adopting Information Technology for SMEs : Experience in Adopting Email within an Indonesian Furniture Company. Electronic Journal of Information Systems Evaluation, 6(2), . 2003, $165-176$.
48. Hollenstein, H., Determinants of The Adoption of Informatioan and Communication Technologies (ICT). "Industrial Dynamics of the New and Old Economy - who is embracing whom, 2002).

49. Barua, A., Whinston, A. B., Konna, P., \& Yin, F., An Assessing Internet Enabled Business Value: An Exploratory. MIS Quarterly, 28(4), 2004, 585-620

50. Al-qirim, N. A. Y., E-commerce in the aerial mapping industry: A New Zealand case study. Journal of Systems and Information Technology, 7(1), . 2003, $67-92$.

51. Chong, S., Success in electronic commerce implementation: A cross-country study of small and medium-sized enterprises. Journal of Enterprise Information Management, 21(5), 2008, $468-492$. doi:10.1108/17410390810904247

52. Bayo-Moriones, A., Billon, M., \& Lera-Lopez, F., Perceived performance effects of ICT in manufacturing SMEs. Industrial Management \& Data Systems, 113(1), . 2013, 117-135. doi:10.1108/02635571311289700

53. Tarute, A., \& Gatautis, R., ICT Impact on SMEs Performance. Procedia - Social and Behavioral Sciences, 110, 2014, 1218-1225. doi:10.1016/j.sbspro.2013.12.968

54. Liang, T.-P., You, J.-J., \& Liu, C.-C., A resource-based perspective on information technology and firm performance: a meta analysis. Industrial Management \& Data Systems, 110(8), 2010, 1138-1158. doi:10.1108/02635571011077807

55. Gosen, J., Creating Comparative Advantage for Micro-Enterprises Through E-Governance. Int. $J$. of Electronic Governance, 2009 Vol.2, No.2/3, pp.239 - 250, 2(2/3), 2009, 239-250

56. Lucia-Palacios, L., Bordonaba-Juste, V., PoloRedondo, Y., \& Grünhagen, M., E-business implementation and performance: analysis of mediating factors. Internet Research, 24(2), 2014, 223-245. doi:10.1108/IntR-09-2012-0195 57. Maldeni, H. M. C. M., \& Jayasena, S., Information and Communication Technology Usage and Bank Branch Performance. The International Journal on Advances in ICT for Emerging Regions 2009, 02(02), 2009, 29-37

58. Apulu, I., \& Latham, A., Drivers for Information and Communication Technology Adoption: A Case Study of Nigerian Small and Medium Sized Enterprises. International 
Journal of Business and Management, 6(5), 2011, 51-60. doi:10.5539/ijbm.v6n5p51

59. Bharadwaj, A.S., "A resource-based perspective on information technology capability and firm performance: an empirical investigation", $M I S$ Quarterly, Vol. 24 No. 1, 2000, pp. 169-196.

60. Liang, T.-P., You, J.-J., \& Liu, C.-C., A resource-based perspective on information technology and firm performance: a meta analysis. Industrial Management \& Data Systems, 110(8), 2010, 1138-1158. doi:10.1108/02635571011077807

61. Das, S., Yaylacicegi, U., \& Menon, N. M., The Effect of Information Technology Investments in Healthcare: A Longitudinal Study of its Lag, Duration, and Economic Value. IEEE Transactions on Engineering Management, 58(1), 2011, 124-140. doi:10.1109/TEM.2010.2048906

62. Lii, Ys., Lim, H., \& Tseng, L., 'The effects of web operational factors on marketing performance', Journal of American Academy of Business, vol. 5(1/2), 2004, pp. 486- 494

63. Delone, W. H., \& Mclean, E. R., Measuring eCommerce Success: Applying the DeLone \& McLean Information Systems Success Model. International Journal of Electronic Commerce, 9(1), 2004, 31-47

64. Kotelnikov, V., Small and Medium Enterprises and ICT. Asia-Pacific Development Information Programme, 2007).

65. Tan, K. S., Chong, S. C., Lin, B., \& Eze, U. C., Internet-based ICT Adoption Among SMEs: Demographic versus Benefits, Barriers, and Adoption Intention. Journal of Enterprise Information Management, 23(1), 2010, 27-55. doi:10.1108/17410391011008897

66. Young, D., \& Benamati, J., Differences In Public Web Sites: The Current State Of Large U . S . Firms. Journal of Electronic Commerce Research, 1(3), 2000, 94-105

67. Alam, S. S., \& Noor, M. K. M., ICT Adoption in Small and Medium Enterprises : an Empirical Evidence of Service Sectors in Malaysia. International Journal of Business and Management, 4(2), 2009, 112-125.

68. Chong, S., An Empirical Study of Factors that Influence the Extent of Deployment of Electronic Commerce for Small- and Mediumsized Enterprises in Australia Electronic Commerce for Small- and Medium-sized Enterprises in Australia. Journal of Theoretical and Applied Electronic Commerce Research, 1(2), 2006, 45-57

69. Gemino, A., Mackay, N., \& Reich, B. H., Executive Decisions About Website Adoption In Small And Medium-Sized Enterprises. Journal of Information Technology Management, XVII(1), 2006, 35-50.

70. Hashim., JInformation Communication Technology ( ICT ) Adoption Among SME Owners in Malaysia. International Journal of Business and Management, 2(2), 2007, 221240.

71. Jeon, B. N., Han, K. S., \& Lee, M. J. Determining factors for the adoption of ebusiness: the case of SMEs in Korea. Applied Economics, 38(16), 2006, 1905-1916. doi:10.1080/00036840500427262

72. Auger, P., Barnir, A., \& Gallaugher, J. M., Strategic Orientation, Competition, and Internet-Based Electronic Commerce. Information Technology and Management, 4, 2003, 139-164

73. Vilaseca-Requena, J., Torrent-Sellens, J., Meseguer-Artola, A., \& Rodríguez-Ardura, I., An Integrated Model of the Adoption and Extent of E-Commerce in Firms. International Advances in Economic Research, 13(2), 2007, 222-241. doi:10.1007/s11294-006-9061-z

74. Raymond, L. Determinants of Web Site Implementation in Small Businesses. Internet Research; Electronic Networking Applications and Policy, 11(5), 2001, 411-422.

75. Hameed, M. A., \& Counsell, S., Assessing the Influence of Environmental and CEO Characteristics for Adoption of Information Technology in Organizations. Journal of Technology Management \& Innovation, 7(1), 2012, $65-84$

76. Kuan, K. K. Y., \& Chau, P. Y. K., A perception-based model for EDI adoption in small businesses using a technologyorganization-environment framework. Information \& Management, 38(8), 2001, 507521. doi:10.1016/S0378-7206(01)00073-8

77. Tigre, P. B., Brazil in the Age of Electronic Commerce. The Information Society, 19, 2003, 33-43. doi:10.1080/01972240390145652

78. Gibbs, J., Kraemer, K. L., \& Dedrick, J., Environment and Policy Factors Shaping Ecommerce Diffusion: A Cross-Country Comparison. The Information Society, 19(1), 2003, 5-18 
79. Costello, P., Sloane, A., \& Moreton, R., IT Evaluation Frameworks - Do They Make a Valuable Contribution? A Critique of Some of the Classic Models for use by SMEs. EJISE, 10(1), 2007, 57-64.

80. Paul, a. K., \& Anantharaman, R. N,. Impact of people management practices on organizational performance: analysis of a causal model. International Journal of Human Resource Management, 14(7), 2003, 1246-1266. doi:10.1080/0958519032000145648

81. Dedrick, J., Gurbaxani, V., \& Kraemer, K. L. Information Technology and Economic Performance: A Critical Review of the Empirical Evidence. ACM Computing Surveys, 35(1), 2003, 1-28

82. Iacovou, C. L., Benbasat, I., \& Dexter, A. S., Electronic Data Interchange and Small Organizations; Adoption and Impact of Technology. MIS Quarterly, 19(4), 1995, 465485.

83. Melville, B. N., \& Kraemer, K. Review: Information Technology and Organizational Performance : An Integrative Model of IT Business Value. MIS, 2004. 28(2), 283-322.

84. Jacks, T., Palvia, P., Schilhavy, R., \& Wang, L. A Framework for The Impact of IT on Organizational Performance. Business Process Management Journal, 2011. 17(5), 846-870. doi:10.1108/14637151111166213

85. Anh, P. C., \& Matsui, Y. (2011). Relationship between quality management information and operational performance: International perspective. Management Research Review, 34(5), 519-540. doi:10.1108/01409171111128706 